\title{
PERANCANGAN RUANG CAMPURAN ANTARA DUNIA VIRTUAL DENGAN DUNIA FISIK SEBAGAI OBJEK WISATA ARSITEKTUR DI JALAN JUANDA
}

\author{
Christian Wijaya ${ }^{1)}$, Petrus Rudi Kasimun ${ }^{21}$ \\ ${ }^{1)}$ Program Studi S1 Arsitektur, Fakultas Teknik, Universitas Tarumanagara, chris.wjya11@gmail.com \\ 2) Program Studi S1 Arsitektur, Fakultas Teknik, Universitas Tarumanagara, petrusk@ft.untar.ac.id
}

\begin{abstract}
Abstrak
Dengan semakin padatnya kota Jakarta sebagai kota metropolis, pembangunan wisata menjadi sesuatu yang tidak diperhatikan di dalam kota Jakarta. Terjadi sebuah sentralisasi, dimana perkembangan wisata kota Jakarta hanya terjadi di kawasan tertentu. Salah satu alasan kurang berkembangnya wisata dalam kota Jakarta adalah adanya perebutan ruang kota antara kebutuhan sehari-hari masyarakat dengan kebutuhan akan wisata. Wisata arsitektur menjadi penyeimbang bagi dua kebutuhan yang terlihat bertolak belakang ini. Wisata merupakan usaha untuk berekreasi, yaitu mengalihkan diri dari kehidupan sehari-hari. Namun bagi masyarakat modern, pengalihan tersebut tersedia dalam bentuk media digital yang sekarang ini ada di mana-mana. Media digital menjadi sebuah media rekreasi yang biasa digunakan masyarakat modern. Daya tarik sebuah media digital dengan dunia virtualnya yang mudah mengalihkan seseorang dari kehidupan sehari-harinya membuat kebutuhan akan sebuah wisata fisik seakan-akan menurun. Fenomena ini perlu diatasi untuk dapat meningkatkan wisata di dalam kota Jakarta yang berpotensi sebagai destinasi wisata dengan banyaknya sumber daya. Perlu adanya sebuah pertemuan antara dunia virtual dan dunia fisik dalam konteks wisata agar dapat terciptanya sebuah objek wisata yang memiliki daya tarik di tengah-tengah kota modern Jakarta yang padat. Arsitektur sebagai pembentuk dunia fisik berperan dalam menjebatani dua dunia yang tampak berbeda ini, sebuah elemen yang dapat bertransfromasi dalam ruang campuran, dimana dunia fisik dan dunia virtual dapat bertemu dan saling berinteraksi dalam konteks wisata, diharapkan kegiatan wisata di Jakarta dapat meningkat dan memiliki daya tarik bagi masyarakat modern yang memiliki akses ke berbagai media wisata untuk berekreasi, mengalihkan diri dari kehidupan sehari-hari.
\end{abstract}

Kata kunci: Dunia Virtual; Kota Metropolis; Transformasi; Ruang Campuran; Wisata Arsitektur

\begin{abstract}
With increasing density within the city of Jakarta as a metropolis city, tourism development became something to ignore within the city of Jakarta itself. There's a tourism centralization, which makes the development only limited within a certain area. One of the reason why tourism haven't been developed in Jakarta would be because of the scramble of city spaces between dweller's daily life and tourism. Architecture tourism could be the balance between the two seemingly opposite needs. Tourism itself is a means to recreate, which mean to distract oneself from his/her own daily life. However, for a modern society, the distraction comes in a form of digital media that can be found everywhere. Digital media became a recreation media that modern society typically use to distract their attention from their daily lives. The attraction of digital media with its virtual world that can easily distract a person from his/her daily life, makes the needs for physical recreation seems decreasing. This phenomenon needs to be dealt with to improve tourism in Jakarta, that has so much potential to be a tourism destination with it's massive resources. There's a need for a meeting point between virtual world and phsical world within the context of tourism, so there can be a tourism object that has an appeal within a dense modern city like Jakarta. Architecture as the framer of the physical world has a role in bringing the two different world together, an element that can transform within the fusion space. With the present of a fusion space, where physical world and virtual world can meet and interact with one another within the context of tourism, it's expected that tourism in Jakarta can increase and be alluring to the modern society that has multiple medias to recreate, distract themselves from their daily lives.
\end{abstract}

Keywords: Architecture Tourism; Fusion Space; Metropolis City; Transformabel; Virtual World 


\section{PENDAHULUAN}

Jakarta merupakan sebuah kota metropolis yang tiap tahun menarik pendatang baru untuk tinggal di dalam Jakarta. Dengan segala kemajuannya, Jakarta menjadi sebuah tempat yang dituju bagi masyarakat untuk tinggal. Namun, Jakarta semata-mata hanya sebuah lahan untuk bekerja. Kepadatan kota Jakarta sebagai kota metropolis menggeser kegiatan wisata keluar kota Jakarta itu sendiri. Jakarta tidak memiliki banyak daya tarik wisata yang dapat memuaskan keinginan masyarakatnya untuk berwisata. Semakin padatnya kota Jakarta baik secara jumlah manusia maupun kepadatan bangunannya, mempersulit berkembangnya pariwisata di Jakarta. Namun hal itu bukanlah tidak mungkin.

Banyak kota-kota metropolis yang berhasil menggembangkan pariwisatanya melalui pariwisata arsitektur. Pariwisata arsitektur merupakan sebuah pariwisata yang dapat berjalan bersamaan dengan pengembangan kota. Pariwisata arsitektur tidak menutup kemungkinan sebuah bangunan dengan fungsi penunjang kehidupan sehari-hari menjadi sebuah objek wisata. Hal ini membantu menyambung kebutuhan akan wadah sehari-hari yang sangat dibutuhkan oleh kota metropolis dengan nilai sebuah objek wisata.

Minat akan sebuah objek wisata di kota Jakarta mulai tersainggi oleh minat terhadap dunia digital yang sekarang ini sedang berkembang dengan pesat. Kebanyakan masyarakat Jakarta memilih untuk berjalan-jalan di dunia maya dibandingkan dengan berjalan di sebuah objek wisata yang ada di Jakarta. Berkembangnya minat akan dunia digital juga didukung oleh berkembangnya teknologi layar yang saat ini muncul berupa gawai. Berkembangnya teknologi gawai mempermudah berbagai macam aspek kehidupan termasuk berekreasi. Mengalihkan diri dari kehidupan sehari-hari yang melelahkan menjadi semakin mudah dengan munculnya gawai, yang akhirnya kebutuhan untuk mencari rekreasi dapat terpenuhi hanya di dalam gengaman.

\section{Permasalahan}

Objek wisata selalu berhubungan dengan lokasi dimana objek itu berada. Dengan keterbatasannya ruang di dalam kota metropolis, terjadi perebutan ruang kota antara kebutuhan akan wisata dengan kebutuhan akan penunjang kehidupan sehari-hari. Sering kali hal ini terjadi karena objek tersebut hanya memiliki daya tarik bagi pengunjung dan bukannya penduduk lokal atau sebaliknya. Perlu adanya sebuah objek wisata yang dapat menyeimbangkan keduanya agar tetap memiliki daya tarik sebagai objek wisata bagi pengunjung maupun penduduk lokal kota.

Perkembangan teknologi membuka banyaknya kemungkinan penerapan teknologi dalam sebuah objek wisata. Di saat yang bersamaan, perkembangan teknologi juga dapat menurunkan minat terhadap sebuah objek wisata yang cenderung lebih sulit dicapai dibandingkan dengan sebuah layar televisi, gawai, atau komputer. Hal ini membuat kegiatan berwisata seolah-olah dapat dilakukan melalui sebuah layar dalam kehidupan sehari-hari, yang bertolak belakang dengan wisata itu sendiri dimana kegiatan wisata merupakan sebuah kegiatan yang berada di luar kegiatan sehari-hari seorang individu. Objek wisata di tengahtengah kota metropolis yang tentunya perlu memperhatikan masalah ini. Dengan teknologi yang terus berkembang, pengembangan objek wisata sendiri perlu menjadikan perkembangan teknologi sebagai daya tarik wisata agar tetap dapat relevan dengan dunia modern yang penuh dengan teknologi yang berkembang pesat.

\section{Tujuan}

Dengan adanya sebuah objek wisata yang relevan dengan kebutuhan pengunjung dan penduduk lokal, diharapkan pariwisata tetap dapat berkembang di Jakarta. Sehingga kota Jakarta tidak hanya menjadi tempat bagi kehidupan sehari-hari, tetapi juga dapat menjadi tempat untuk mengalihkan diri dari kehidupan sehari-hari itu sendiri, menjadi sebuah tempat berekreasi. Selain itu kehadiran objek wisata yang relevan, juga diharapkan dapat menciptakan 
gambaran baru bagi kota Jakarta sebagai destinasi wisata yang dapat bersaing dengan dunia modern melalui penggunaan teknologi serta menawarkan ide-ide baru dalam pengembangan objek wisata di kota Jakarta untuk kedepannya.

\section{KAJIAN LITERATUR}

Pariwisata merupakan sebuah bagian dari budaya manusia. Arsitektur selain menjadi penunjang bagi pariwisata tersebut, juga dapat menjadi pariwisata itu sendiri. Inti dari pariwisata adalah usaha manusia dalam memuaskan keinginan dirinya, dan arsitektur itu sendiri tercipta atas dasar sebuah keinginan. Menjadikan arsitektur itu sendiri sebagai objek yang dapat memenuhi keinginan seseorang dalam berwisata. (Jan, 2014)

Sebuah objek wisata arsitektur bukan hanya berfokus pada bentukan yang menarik tetapi juga memiliki kemampuan untuk memenuhi keinginan yang tidak hanya dapat dicapai melalui bentuk. Tentunya kegiatan wisata yang dapat dilakukan juga perlu memiliki daya tarik yang membuat objek wisata tersebut bukan hanya sebuah pemanis yang hanya dapat dilihat. Untuk dapat menjadi objek wisata yang berkelanjutan, sebuah objek wisata bukan hanya melihat berdasarkan tapak tilas yang ada, melainkan melihat fenomena yang sedang berkembang. Fenomena yang diangkat kali ini adalah meningkatnya peran layar sebagai sumber rekreasi masyarakat modern. Sebab dari terjadinya fenomena ini dapat dijadikan acuan dalam mengatasi permasalahan dalam mengembangkan sebuah objek wisata yang berkelanjutan di dalam sebuah kota metropolis.

Meningkatnya penggunaan layar bukanlah sebuah bentuk dari kecanduan, melainkan pemenuhan kebutuhan. Manusia memiliki kebutuhan untuk mencari informasi, kebutuhan akan tempat untuk berelasi juga kebutuhan akan dorongan adrenalin yang berhubungan dengan dopamin. Kebutuhan inilah yang meningkatkan penggunaan layar bukan sebuah kecanduan. Sebuah kebutuhan perlu untuk dipenuhi, sebelum berkembangnya layar kebutuhan itu tetap dapat dipenuhi. Namun, seiring berjalannya waktu kehidupan manusia semakin padat dan berkembangnya layar mempermudah memenuhi kebutuhan tersebut. Untuk menyeimbangkan penggunaan layar, yang dilakukan bukanlah sebuah tanggapan terhadap sebuah kecanduan melainkan usaha memenuhi sebuah kebutuhan. Saat ini dunia digitallah yang dapat dengan mudah memenuhi kebutuhan tersebut, maka penggunaan layar itu sendiri sebagai akses ke dunia digital terus bertumbuh. (Cashmore, Cleland, \& Dixon, 2018)

Objek wisata yang dapat bersaing dengan cepatnya pertumbuhan teknologi layar dapat memanfaatkan pertumbuhan teknologi itu sendiri. Berdasarkan apa yang ditulis oleh Ellis Cashmore, meningkatnya penggunaan layar dikarenakan alasan tertentu yaitu untuk memenuhi kebutuhan yang ada. Kemampuan untuk memenuhi kebutuhan tersebut dapat menjadi dasar dalam pengembangan sebuah objek wisata.

Dalam hal ini kebutuhan tersebut dipenuhi melalui bentuk digital dan dunia digital tersebut telah menjadi sebuah dunia yang familiar dan bahkan didambakan bagi kebanyakan masyarakat. Sekarang ini banyak masyarakat modern yang menjalankan kehidupannya di dunia digital tersebut yang bersifat virtual. Dunia virtual tentu berbeda dengan dunia nyata, yang memberinya daya tarik sebagai sebuah media rekreasi. Rekreasi merupakan sebuah pengalihan dari kehidupan sehari-hari, dan dunia virtual merupakan dunia yang berbeda dengan kehidupan sehari-hari.

Menurut Nicky Yee, seorang peneliti asal Amerika Serikat, ada 3 komponen utama seseorang memilih dunia virtual sebagai media rekreasi terutama video games. Ketiga komponen tersebut dijabarkan menjadi, rasa pencapaian yang didapat dalam melakukan aktifitas virtual, penyelaman ke dalam dunia virtual yang berbeda dengan dunia nyata, tersedianya wadah sosial di dalam dunia virtual. (Yee, 2006). Dengan begitu tergantungnya masyarakat modern dengan teknologi, kecenderungan seseorang untuk berekreasi di dalam sebuah dunia virtual menjadi sebuah kebiasaan. Kebiasaan ini membuat bertambahnya waktu layar seseorang dan berkurangnya waktu di dalam dunia nyata. Dengan segala hal yang dapat 
dilakukan dalam dunia virtual yang begitu menarik, masyarakat modern dapat dikatakan menghidupi sebagian besar hidupnya di dalam dunia virtual. Namun dengan segala yang ditawarkan oleh dunia virtual, pemanfaatan dunia virtual yang baik dapat meningkatkan kegiatan rekreasi yang dapat dilakukan.

Dubit, sebuah perusahaan penelitian berfokus pada anak-anak, menemukan bahwa antusias belajar seorang anak meningkat ketika anak tersebut dapat berinteraksi langsung dengan bahan pembelajaran yang dibahas. Hal ini disebabkan oleh dorongan kreatifitas seorang anak ketika dapat berinteraksi langsung. (Dubit, 2015)

Dunia virtual dapat digunakan sebagai sebuah media untuk pembelajaran dan rekreasi yang interaktif. Dengan menjaga keseimbangan antara dunia virtual dengan dunia nyata, maka kegiatan rekreasi yang menarik tidak harus berada di dalam dunia virtual seutuhnya. Arsitektur sebagai pembangun dunia nyata tentunya berperan dalam kemungkinan adanya kegiatan rekreasi yang memiliki daya tarik dunia virtual di dalam dunia nyata.

Selama ini arsitektur dan dunia virtual hanya dilihat sebagai dua dunia yang terpisah, seakan-akan kedua dunia ini merupakan sesuatu yang bertolak belakang, seperti binari komputer 1 atau 0 . Sebuah ruang dimana dunia nyata dengan dunia virtual saling berinteraksi bukanlah tidak mungkin. Dunia vitual yang merespon keadaan yang ada di dunia nyata dan memberikan umpan balik dalam bentuk virtual bukanlah tidak mungkin dengan teknologi yang sekarang ini semakin berkembang. Ruang campuran adalah persimpangan antara dunia virtual dengan dunia fisik. (Flachbart, Weibel, Batsky, Bouman, \& Deutsch, 2005)

\section{METODE}

Metode yang digunakan adalah metode kualitatif dengan studi literatur dan studi kasus sebagai acuan dalam menyusun tulisan. Metode pengamatan dan wawancara digunakan untuk mencari data yang relevan. Dalam merancang metode yang digunakan adalah pengabungan antara dunia virtual dengan dunia fisik. Metode ini didasarkan oleh studi literatur yang dilakukan.

Studi literatur dilakukan dengan mencari literatur yang relevan sebagai dasar dalam penelitian. Studi kasus dilakukan dengan mencari kasus-kasus serupa yang kemudian dapat dijadikan acuan secara nyata. Metode pengamatan digunakan untuk dapat mencari data yang relevan dengan bahasan yang ada. Metode wawancara digunakan untuk menambahkan data yang tidak didapat oleh penulis melalui pengamatan.

\section{DISKUSI DAN HASIL}

\section{Program Wisata}

Berdasarkan kajian yang ada, objek wisata yang memasukan dunia virtual ke dalam sebuah ruang bermain menjadi jawaban yang diambil sebagai wisata arsitektur di dalam kota metropolis Jakarta. Program wisata ini didasarkan oleh kebutuhan-kebutuhan manusia yang ditulis oleh Ellis Cashmore sebagai alasan meningkatnya penggunaan layar juga 3 komponen yang disebutkan oleh Nicky Yee sebagai komponen pendorong seseorang bermain dalam dunia virtual. Dengan memberikan wadah untuk berelasi dan bermain di dalam sebuah ruang campuran antara dunia virtual dengan dunia nyata, maka keduanya dapat terpenuhi.

Penggunaan dunia virtual di sini dilakukan dengan menggunakan teknologi Augmented Reality $(A R)$, yang dapat membuat dunia virtual dapat berinteraksi dengan dunia nyata. Berbeda dengan Virtual Reality $(V R)$, teknologi $A R$ tidak sepenuhnya menggantikan realita yang ada dengan realita yang baru (realita virtual). Namun realita virtual dimasukan ke dalam dunia nyata sehingga kedua realita ini saling menumpuk menciptakan sebuah gabungan antara keduanya. Di sinilah arsitektur dapat berperan, berbeda dengan $V R$ dimana arsitektur yang ada di dunia nyata seluruhnya akan digantikan dengan dunia virtual. Teknologi $A R$ mengharuskan penggunanya tetap berinteraksi dengan dunia sekitarnya, sehingga arsitektur diperlukan tidak hanya sebagai wadah kegiatan tapi juga sebagai wadah dari teknologi tersebut, 
memungkinkan adanya interaksi antara dunia virtual dengan dunia nyata. Secara garis besar, kegiatan wisata ini merupakan kegiatan bermain dengan menggunakan perangkat $A R$ dalam permainan. Permainan yang diangkat merupakan permainan-permainan

Karena teknologi $A R$ yang memerlukan arsitektur sebagai pembangun ruangnya maka dalam merancang standar-standar yang digunakan merupakan standar-standar dasar arsitektur. Literatur arsitektur seperti Neufert Architects' Data (Neufert \& Neufert, 2012) dan Time-saver standard (De Chiara \& Crosbie, 2001) digunakan sebagai pedoman dalam merancang bangunannya.

\section{Pemilihan Tapak}

Dalam memilih tapak yang akan menjadi lokasi objek wisata terdapat beberapa kriteria yang menjadi pedoman dalam pemilihan. Kriteria pertama adalah perekonomian kawasan tapak. Kriteria ini berdasarkan salah satu pembahasan dalam buku Architectural Tourism: Building for Urban Travel Destinations (Jan, 2014), yang membahas bagaimana objek wisata terkadang menggeser pemukiman penduduk lokal yang tidak mampu bertahan di kawasan tersebut karena meningkatnya biaya hidup. Penggeseran ini menyebabkan adanya penolakan dari penduduk lokal terhadap pengunjung-pengunjung objek wisata yang ada di sebuah kota. Kota Jakarta merupakan kota yang sudah sangat padat, dengan datangnya pengunjungpengunjung yang berwisata, tidka menutup kemungkinan adanya pertentangan dari penduduk lokal yang merasa tergeser oleh berkembangnya wisata di Jakarta. Kawasan dengan perekonomian menengah atas memiliki ketahanan yang lebih tinggi terhadap meningkatnya biaya hidup, sehingga kemungkinan terjadinya pertentangan penduduk lokal lebih sedikit.

Di dalam Diffusion of Innovations (Rogers, 2003), dibahas tahapan terjadinya sebuah trend dengan golongan yang disebut early adopters sebagai pendorong dari sebuah trend. Early adopters berdasarkan penjelasan Everett Rogers memiliki beberapa ciri, salah satunya adalah tingkat ekonomi menengah atas. Dari kedua bahasan yang ada, kawasan dengan tingkat ekonomi menengah atas dapat menjadi kawasan yang baik dalam menggembangkan sebuah objek wisata. Sebuah objek wisata yang berada di kawasan dengan tingkat ekonomi menengah atas kecil kemungkinanya menggeser penduduk lokal yang sudah terlebih dahulu ada. Di saat yang bersamaan dapat lebih mudah ditemukan oleh early adopters yang berada di kawasan tersebut untuk menjadikan objek wisata tersebut sebuah tren.

Kriteria berikutnya adalah aksesibilitas baik untuk kendaraan pribadi maupun kendaran umum. Bagi sebuah objek wisata di kota metropolis kemudahan mencapai objek tersebut menjadi sangat penting. Kepadatan di kota metropolis dapat menyebabkan mengunjungi sebuah objek wisata memerlukan usaha yang besar sehingga calon pengunjung enggan untuk mencoba mengunjungi objek wisata tersebut.

Kriteria berikutnya adalah peruntukan dan pemanfaatan lahan yang berlaku. Berada di kota metropolis, kesesuaian dengan peraturan yang ada menjadi sangat penting terlebih lagi terkait peruntukan dan pemanfaatan. Pemerintah daerah Jakarta telah mengatur keduanya dalam Rencana Detail Tata Ruang (RDTR). RDTR menyesuaikan peruntukan dan pemanfaatan dengan kawasan baik secara eksisting maupun rencana kedepannya. Sehingga penyesuaian peruntukan dan pemanfaatan objek wisata dengan RDTR yang berlaku menjadi kriteria dalam memilih tapak.

Kriteria berikutnya adalah kawasan yang sarat akan aktifitas. Rekreasi merupakan sebuah pengalihan (Merriam-Webster, 1993). Dalam hal ini rekreasi merupakan pengalihan dari kehidupan sehari-hari yaitu bekerja, sekolah, berdagang, dsb. Oleh karena itu lebih baik jika objek wisata ini berada di kawasan yang sarat akan aktifitas, sebagai sebuah wisata rekreasi yang mengalihkan pengunjung dari kehidupan sehari-harinya.

Kriteria yang terakhir adalah kemungkinan diterapkannya urban infill. Urban infill adalah pengembangan atau pengembangan kembali sebuah lahan kosong atau lahan yang kurang dimanfaatkan (Southern Nevada Regional Planning Coalition, 2013). Penerapan urban infill 
dalam pengembangan kembali lahan yang kurang dimanfaatkan memiliki pengecualian yaitu bangunan cagar budaya yang lahannya tidak boleh dikembangkan kembali menjadi bangunan baru. Jadi lahan yang boleh dikembangkan kembali adalah lahan dengan bangunan non cagar budaya. Di dalam sebuah kota metropolitan yang padat, penggunaan lahan kosong atau lahan yang kurang dimanfaatkan dapat membantu mengatasi masalah kepadatan yang ada. Oleh karena itu kemungkinan penerapan urban infill menjadi kriteria dalam memilih tapak.

Berdasarkan kelima kriteria yang ada, tapak yang terpilih berada di Kecamatan Gambir, Jakarta Pusat. Tepatnya berada di ruas Jl. Ir. H Juanda.

Tapak berada di kawasan Gambir, Jakarta Pusat dengan tingkat perekonomian menengah atas. Berada di ruas JI. Ir. H. Juanda yang merupakan ruas jalan arteri (lihat gambar 1). Lokasi tapak berada kurang dari 100 meter dari stasiun kereta Commuter Line dan halte bus Trans Jakarta, sehingga tapak memiliki aksesibilitas yang baik (lihat gambar 1). Dalam RDTR 2030 yang disahkan pada tahun 2014, lahan berperuntukan zona perdagangan dan jasa dengan koefisien dasar bangunan (KDB) sebesar 60\%, koefisien lantai bangunan (KLB) sebesar 2.4, ketinggian bangunan yang diperbolehkan (KB) sebesar 4. Peruntukan dan pemanfaatan lahan sesuai dengan kriteria. Tapak berada di kawasan perdagangan, perkantoran, pemerintahan dan juga pendidikan, sehingga kawasan sarat akan aktifitas sehari-hari yang sesuai dengan kriteria tapak. Terdapat bangunan tua non cagar budaya di atas lahan tapak terpilih yang tidak menggunakan lahan secara maksimal sehingga dimungkinkan adanya urban infill.

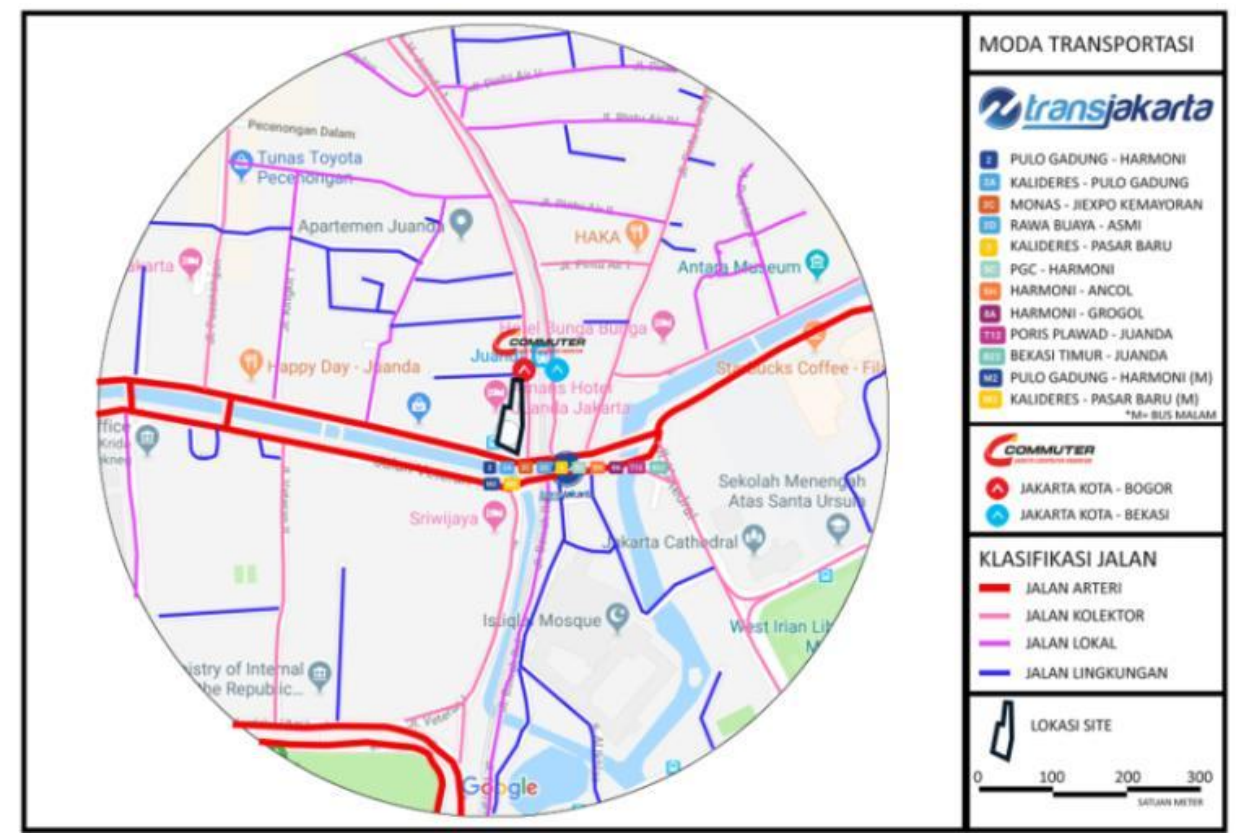

Gambar 1. Lokasi dan informasi tapak

\section{Konsep Bangunan}

Konsep bangunan yang digunakan adalah tempat bermain. Dengan menjadikan permainan konvensional seperti perosotan, ayunan, dll sebagai permainan yang akan dimasukan ke dalam bangunan. Juga konsep bermain yang memiliki keluwesan digunakan dalam mengatur organisasi ruang di dalam bangunan.

Konsep bentuk banguan sendiri mengikuti keadaan sekitar baik dari keadaan bangunan sekitar maupun tapak dimana bangunan ini berada. Tapak berada di ruas Jalan Ir. H. Juanda, tepatnya berada di sisi barat dari stasiun Commuter Line Juanda.

Bangunan sekitar tapak yang seragam dengan bentukan kotak dan lokasi tapak yang berdekatan dengan Masjid Raya Istiqlal, membuat dasar bentukan bangunan dibuat kotak untuk menjaga keseragaman dengan bangunan sekitar serta bentuk rasa hormat dengan 
bangunan yang terlebih dahulu ada. (lihat gambar 2). Bangunan juga meresponi bentukan tapak yang ada dengan mempertahankan bentuk kotak sebagai bentuk dasar bangunan (lihat gambar 3).

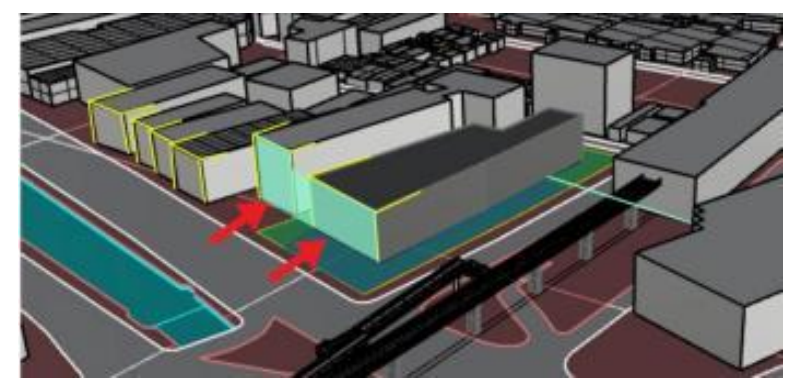

Gambar 2. Pembentukan massing bangunan

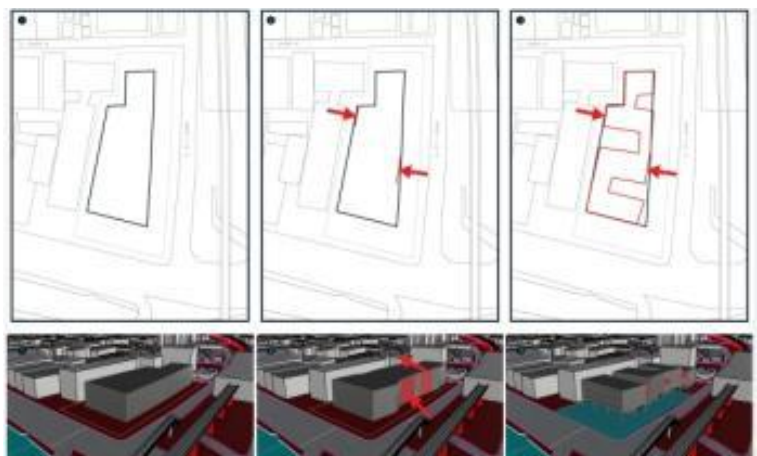

Gambar 3. Penyesuaian bentuk bangunan dengan tapak

Bangunan merupakan sebuah bangunan publik yang mewadahi kegiatan publik. Untuk menarik publik ke dalam bangunan, bagian depan bangunan yang menghadap Jl. Ir. H. Juanda dan Jl. Ir. H. Juanda 1 diangkat sehingga menciptakan ruang semi-outdoor di lantai dasar yang dapat diakses oleh publik (lihat gambar 4). Perlakuan ini didasarkan oleh tingginya intensitas pejalan kaki pada bagian hoek tapak, sehingga diharapkan dapat menarik perhatian pejalan kaki yang berlalu-lalang.

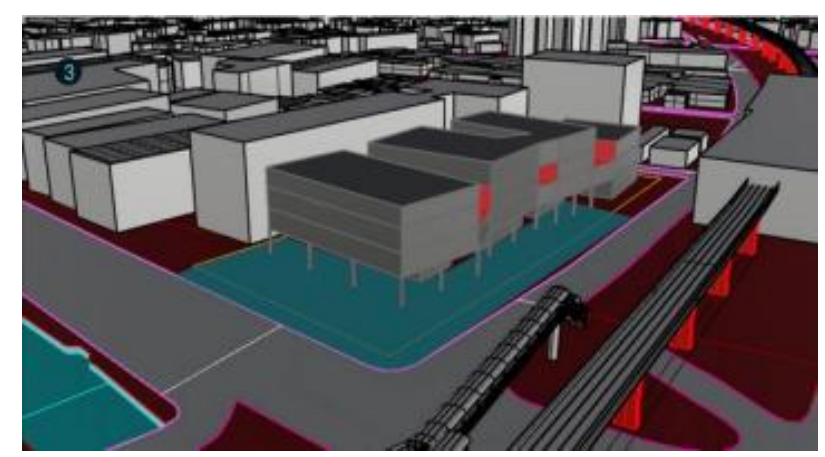

Gambar 4. Ruang semi-outdoor yang dibuat pada bagian hoek bangunan

Bagian dalam bangunan merupakan ruang-ruang bermain dengan konsep ruang bermain konvensional yang umum dijumpai di taman-taman bermain. Penyusunan hubungan antara ruang-ruang ini dibuat melenkung-lengkung agar menjaga unsur permainan yang tidak kaku, menghindari bentukan-bentukan lorong yang berbentuk linear. (lihat gambar 5) 


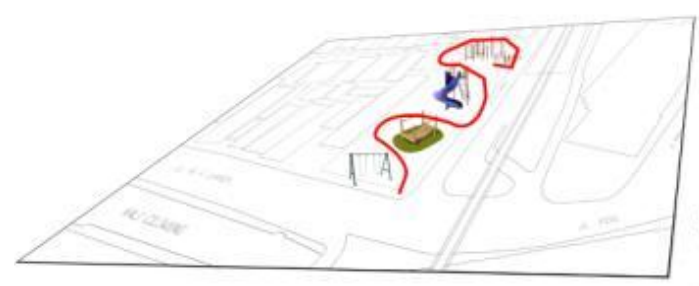

Gambar 5. Konsep hubungan antara ruang

\section{Hasil Rancangan}

Berikut adalah hasil rancangan sebuah objek wisata arsitektur bersifat rekreasi dengan penggunaan teknologi $A R$. Hasil rancangan berupa gambar- gambar siteplan, denah, tampak, dan potongan. (lihat gambar $6-15$ )

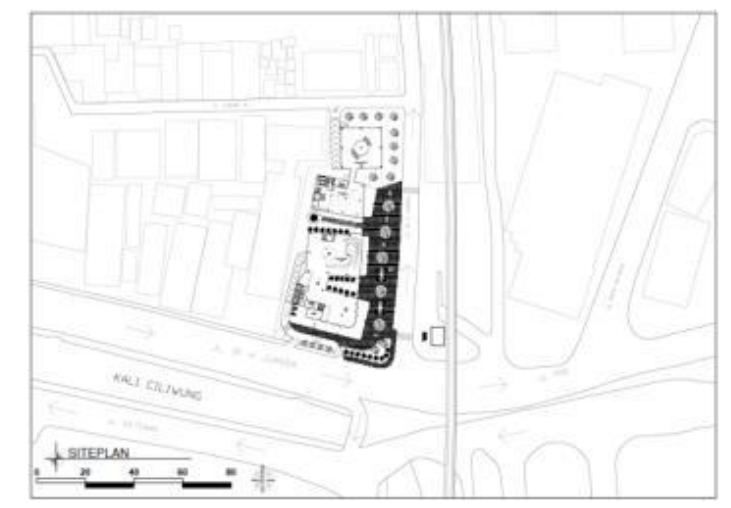

Gambar 6. Siteplan bangunan menunjukan keberadaan bangunan dalam site dan hubungan dengan bangunan sekitar.
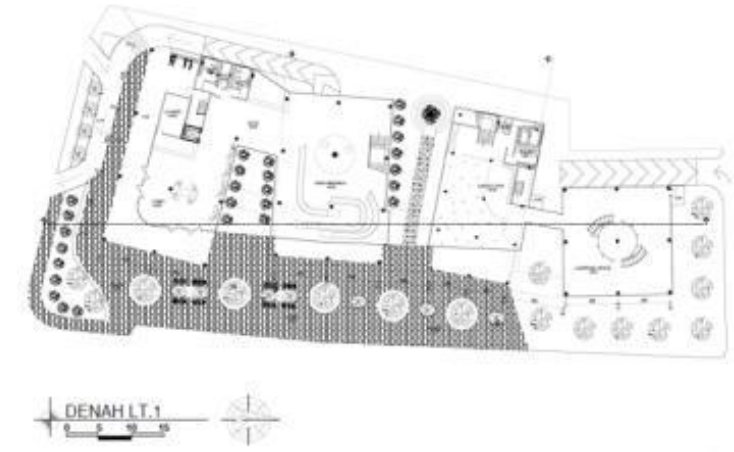

Gambar 7. Denah lantai 1
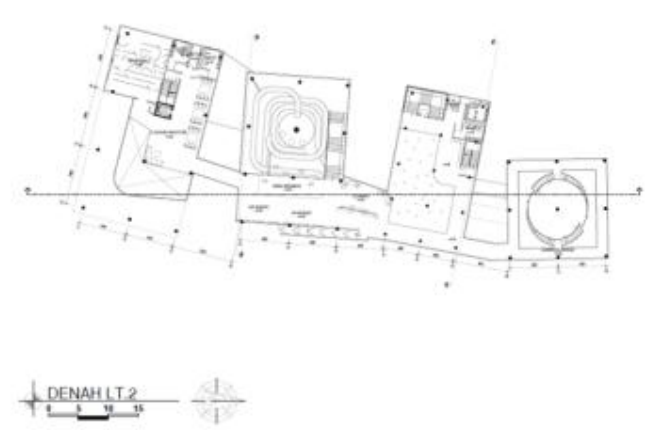

Gambar 8. Denah lantai 2 

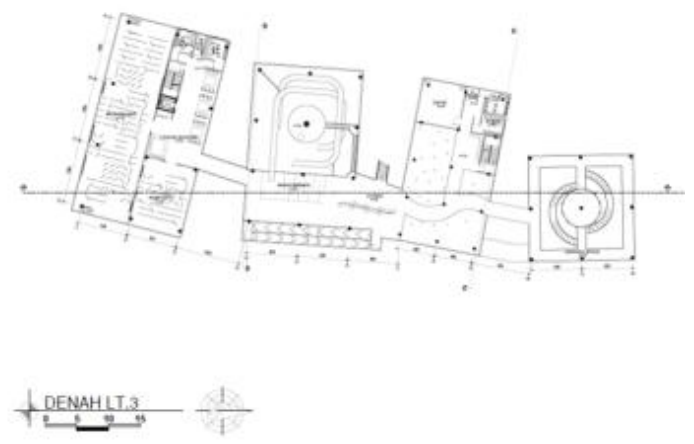

Gambar 9. Denah lantai 3
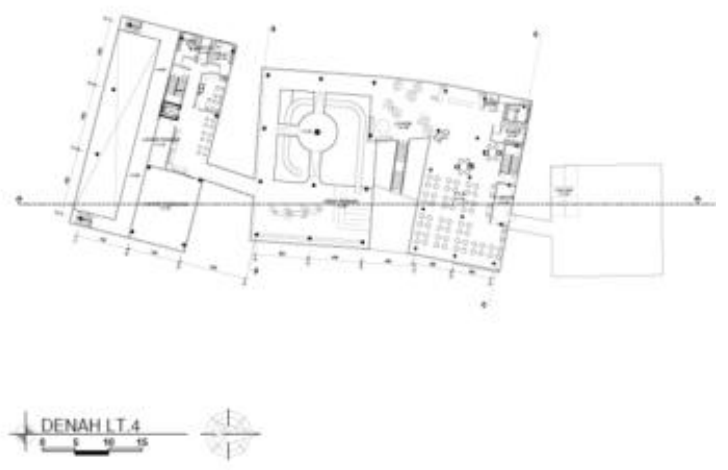

Gambar 10. Denah lantai 4

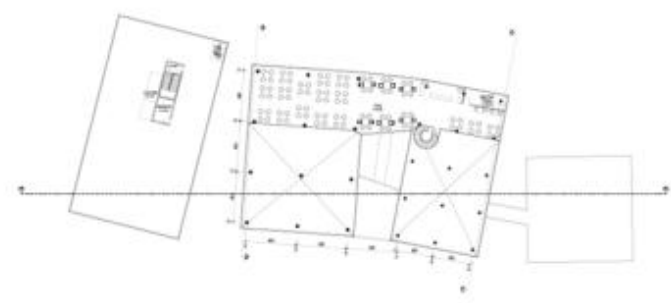

+oEnaHMEZZANINE $-\frac{1}{1}$

Gambar 11. Denah lantai mezzanine

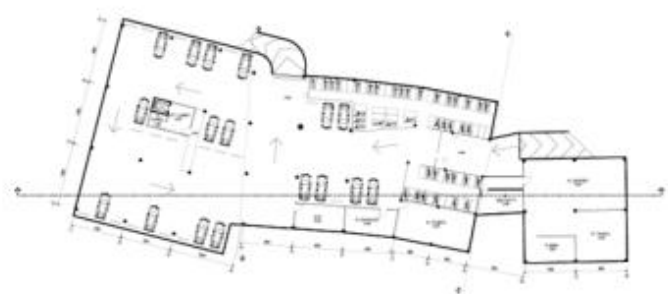

+ DenaHBasement $-\frac{1}{1}$

Gambar 12. Denah lantai basement 

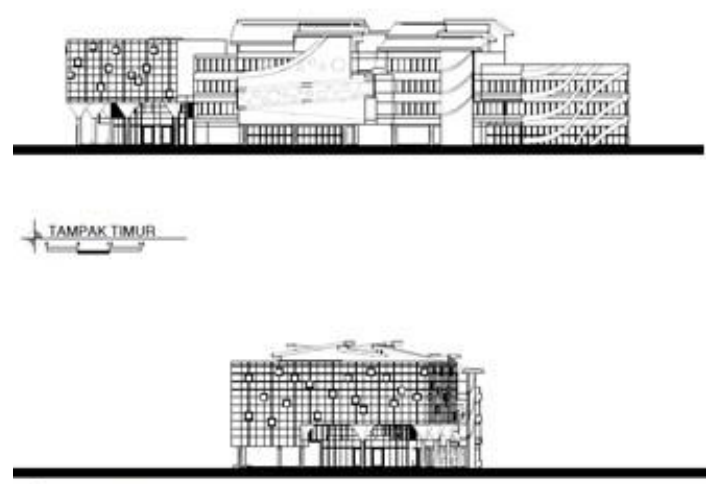

t tampakselatan

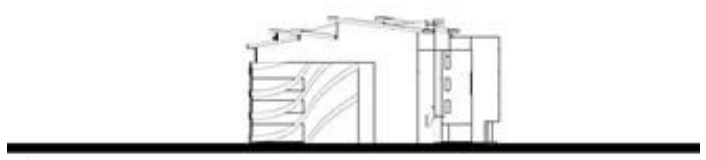

LTMEAKUTABA

Gambar 13. Tampak Bangunan

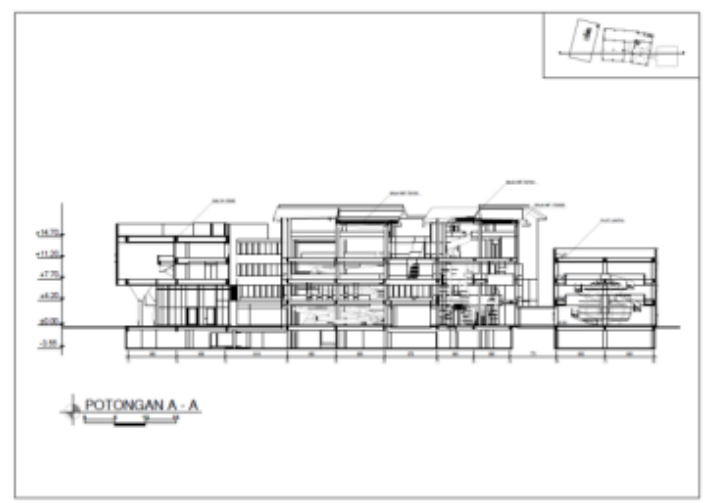

Gambar 14. Potongan A-A

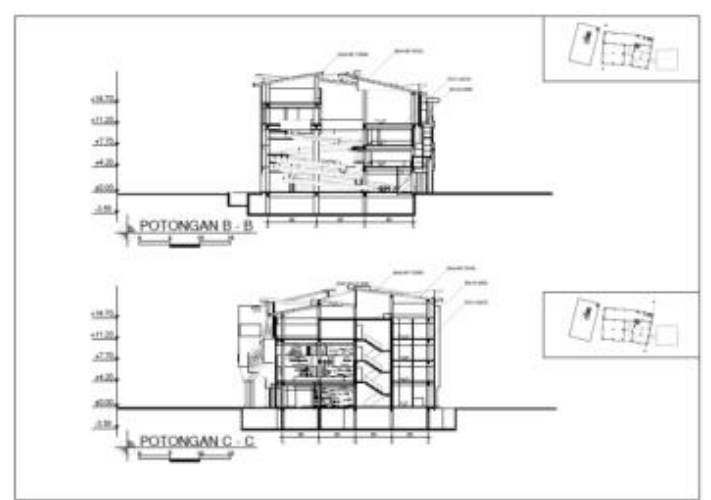

Gambar 15. Potongan B-B dan C-C

Fasade bangunan menggunakan permainan panel LED yang dapat diatur melalui penerapan teknologi maglev sehingga penampilan fasade dapat berubah-ubah. Penerapan teknologi $A R$ membuat penampilan interior bangunan dimungkinkan untuk berganti-ganti sesuai dengan tampilan dunia virtual yang diimplementasikan. Dengan menggunakan panel LED sebagai fasade, maka tidak hanya penampilan interior bangunan saja yang dapat berubah, tetapi juga bagian dari tampak eksterior bangunan, yang diharapkan dapat menjadi daya tarik wisata. 
Penggunaan panel LED ini diterapkan pada bagian depan bangunan yang menjadi bagian pintu masuk dari bangunan (lihat gambar 16 dan 17).

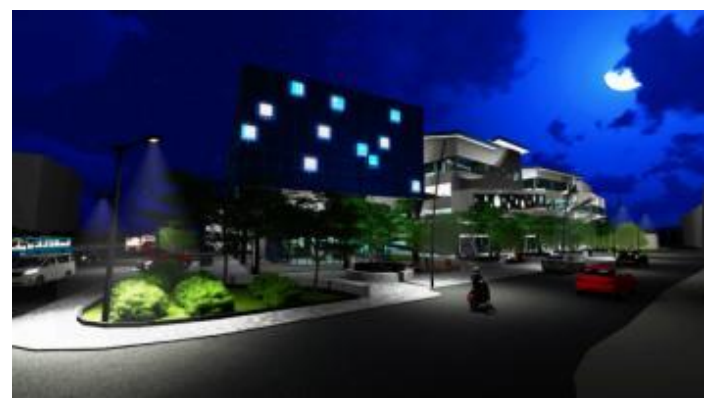

Gambar 16. Penggunaan panel LED pada fasade, alternatif 1

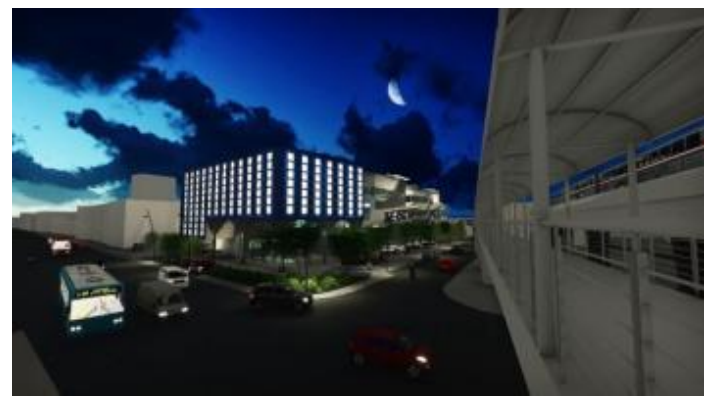

Gambar 17. Penggunaan panel LED pada fasade, alternatif 2

Bagian ruang campuran dalam bangunan merupakan ruang bermain yang memungkinkan adanya sebuah interaksi antara pengunjung, ruang dalam, dengan dunia virtual yang dimasukan melalui teknologi $A R$ (lihat gambar 18). Di dalam ruang campuran ini pengunjung dapat berinteraksi dengan dunia virtual dan juga dunia fisik yang ada di sekitarnya.

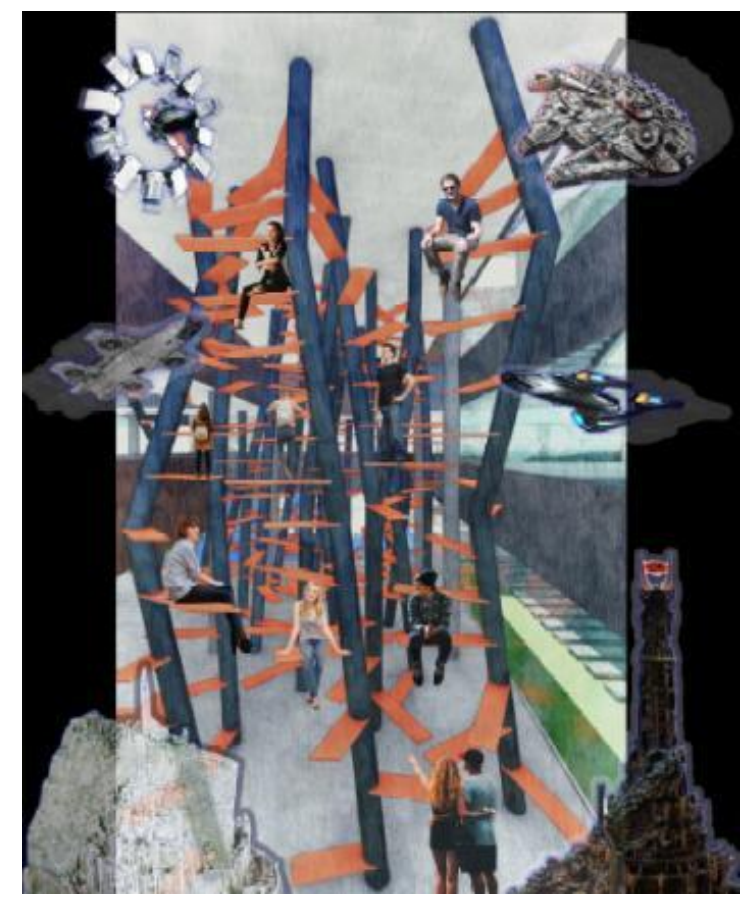

Gambar 18. Ilustrasi ruang campuran 
Selain sebagai media untuk bermain, ruang campuran juga dapat digunakan sebagai media belajar menggunakan teknologi AR. Ruang campuran sebagai media belajar ini berupa sebuah ruangan 3 lantai dengan void dibagian tengah dan bentukan bola kaca di bagian tengah ruangan yang dibuat agar pengunjung yang masuk dapat merasakan ruang campuran yang lebih tertutup dengan dinding bagian dalam bola kaca sebagai pembatas antar ruang campuran yang tercipta dengan ruangan di luarnya. (lihat gambar 19)

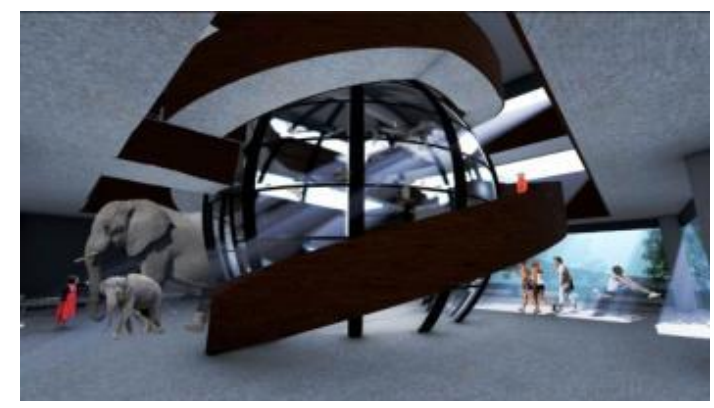

Gambar 19. View ke arah ruang belajar dengan ruangan berbentuk bola di bagian tengah

\section{KESIMPULAN DAN SARAN}

Kegiatan wisata rekreasi yang menggunakan gabungan antara dunia virtual dengan dunia nyata dapat memiliki keunggulan dari teknologi digital dalam menarik penggunanya tanpa menghilangkan orientasinya pada lingkungan sekitarnya. Adanya hubungan yang baik antara dunia virtual dan dunia nyata melalui penerapan arsitektur yang mendukung, dapat menciptakan sebuah ruang menarik yang dapat mengalihkan seseorang dari kehidupan sehariharinya dalam sebuah pengalaman baru di dalam ruang campuran. Dimana pengalihan dari kegiatan sehari-hari merupakan inti dari wisata rekreasi yang diangkat menjadi fokus utama.

Wisata arsitektur dapat menjadi sebuah alternatif wisata yang baik untuk dikembangkan di dalam sebuah kota metropolis. Objek wisata arsitektur dapat memiliki fungsi yang menunjang kehidupan masyarakat lokal dan tetap memiliki daya tarik wisata bagi pengunjungnya. Dengan pengembangan sebuah objek wisata arsitektur, diharapkan jurang antara unsur wisata dan unsur kehidupan sehari-hari dapat mulai dijembatani untuk menciptakan sebuah kota metropolis yang seimbang.

Dalam mernacang sebuah objek wisata arsitektur di dalam sebuah kota metropolis perhatian akan kebutuhan kota dan perkembangan trend dan teknologi yang terjadi menjadi sebuah poin penting. Ruang campuran sebagai objek wisata merupakan pendekatan objek wisata sebagai wisata rekreasi berdasarkan yang dianalisa oleh penulis dari keadaan kota juga trend dan teknologi yang berkembang. Untuk pengembangan berikutnya ruang campuran sebagai objek wisata dapat dilihat sebagai wisata lainnya tidak hanya tertutup sebagai wisata rekreasi.

\section{UCAPAN TERIMA KASIH}

Terima kasih kepada penduduk dan pekerja di sekitar lokasi tapak yang bersedia diwawancari dalam proses pengumpulan data. Terima kasih juga kepada teman-teman yang sudah terus mendukung dan mau berbagi pengetahuan melalui diskusi selama proses pengumpulan data dan perancangan berjalan hingga selesai.

\section{REFERENSI}

Cashmore, E., Cleland, J., \& Dixon, K. (2018). Screen Society. Basingstoke: Palgrave Macmillan. De Chiara, J., \& Crosbie, M. J. (2001). Time-Saver Standards for Building Types, 4th Edition.

New York: McGraw-Hill. 
Dubit. (2015). Exploring Play and Creativity in Pre-Schoolers' Use of Apps: Report for Early Years Practitioners. Leeds: Dubit.

Flachbart, G., Weibel, P., Batsky, A., Bouman, O., \& Deutsch, D. (2005). Disappearing Architecture: From Real to Virtual to Quantum. Birkhäuser Architecture.

Jan, S. (2014). Architectural Tourism: Building for Urban Travel Destinations. Wiesbaden: Springer Gabler.

Merriam-Webster. (1993). Webster's Third New International Dictionary of the English Language. Springfield: Merriam-Webster.

Neufert, E., \& Neufert, P. (2012). Neufert Architect's Data, Fourth Edition. New Jersey: WileyBlackwell.

Rogers, E. M. (2003). Diffusion of Innovations. Massachusetts: Free Press.

Southern Nevada Regional Planning Coalition. (2013). Infill Development Plan. Las Vegas: Southern Nevada Regional Planning Coalition.

Yee, N. (2006). Motivation for Play in Online Games. Cyberpsychology \& behavior: the impact of the Internet, multimedia and virtual reality and behavior and society, 772 - 775 